\title{
Invideo et Amo: On Envying the Beloved
}

\author{
Forthcoming in Philosophia \\ (please cite the final version)
}

Ellis and Richard, two surgery residents, are deeply in love. They have been drawn to each other by a shared passion for medicine, a focused ambition on their career, and a common perception of isolation in a world of people who do not look like them: she, a White woman in a traditionally male environment; he, an African-American man in a predominantly White field. They decide to abandon their spouses, but, just when they are about to elope, Richard changes his mind, without telling her why, and their relationship ends. He cannot bring himself to admit to her that the reason he can't be with her is that he envies her: Ellis has just been nominated for a prestigious award, and he is incapable of rejoicing of her success and of being in a loving relationship with a woman who outperforms him professionally. ${ }^{1}$ Richard's intense envy has thus smothered his intense love.

This story is exemplary of the widespread notion that love and envy are incompatible attitudes, both in the sense that they cannot be felt at the same time toward the same person, and that they are normatively opposed-one a virtue, the other a vice. In this paper I argue

\footnotetext{
${ }^{1}$ Cf. Grey's Anatomy, season 11, episode 4. Here is a synopsis: “[Richard] and Ellis made a pact to leave their spouses. [Ellis] had just received her first Harper Avery nomination. He was hatefully, hopelessly jealous, as if she was already too far ahead to catch up to. Her success illuminated everything he hadn't yet accomplished. The night before the carousel meeting, as he worked up the nerve to tell Adele [Richard's wife], he thought of Ellis and what she could do at such a young age. He thought of what she would do and he realized he didn't want to live his entire life feeling like that, so he ruined their pact." (http://greysanatomy.wikia.com/wiki/Only_Mama_Knows, emphasis mine)
}

Note that Richard says he was "jealous". It is well-known in the psychological literature that English speakers often use "jealousy" as synonym for envy, in virtue of the lesser social and moral stigma that the term carries, compared to "envy". See Smith et al 1988, Parrott 1991, Parrott and Smith 1993, Miceli and Castelfranchi 2007, Smith and Kim 2007. 
that this notion is exceedingly simplistic and that love and envy are compatible in at least two senses: first, they thrive in the same psychological conditions and thus are likely to occur together; second, a love relationship can benefit from (a certain variety of) envy.

\section{Love Does Not Envy. Or Does it?}

In the Scrovegni Chapel in Padua, a famous fresco painted by Giotto depicts seven pairs of opposing virtues and vices, among which are Charity, which is a form of Love, and Envy. Envy is depicted allegorically as a horned, demonic woman with a snake coming out of her mouth only to blind her (to symbolize envy's "evil eye," and its malicious and self-defeating behaviors), a huge ear (for envious people are always alert and curious about other people's lot), one hand protruding like a hook (motivated by the desire to deprive the envied of what one lacks), while the other is holding onto her own possessions. Charity is a beautiful and young woman, indifferent to the bags of money lying at her feet, and looking up, offering her heart to God.

Love and envy are seen as opposite attitudes_-one a virtue, the other a vice-in the Christian tradition. Much earlier than Giotto, St. Paul says that love "does not envy" in Corinthians 13:4 and Basil of Caesarea claims: “... as the red blight is a common pest to corn, so envy is the plague of friendship". 2

But the idea that that love and envy are incompatible is far from being peculiar to Christianity. Widespread spiritual and intellectual traditions such as Judaism, Daoism, Confucianism, Buddhism, Hinduism, and Islam all condemn envy and praise love, and for

\footnotetext{
${ }^{2}$ Basil of Cesarea1950, p. 469.
} 
good reasons. Envy is believed to necessarily involve malice toward the envied, ${ }^{3}$ while love is believed to necessarily involve concern for the beloved's welfare. ${ }^{4}$ Envy's affect is negative, while love's affect is positive, at least in its prototypical form of reciprocated love. Envy often correlates with rejoicing of the envied's misfortune, ${ }^{5}$ whereas love often correlates with rejoicing of the beloved's good fortune.

Many Western philosophers have defined envy as a mixture or a form of hatred, the very opposite of love. ${ }^{6}$ According to Descartes, envy qua passion is "a kind of sadness mingled with hatred, arising from our seeing good coming to those we think unworthy of it". For Spinoza, "Envy is hatred in so far as it affects a man so that he is sad at the good fortune of another person and is glad when any evil happens to him"». Hume says of malice that it imitates the effects of hatred and makes us rejoice in the suffering of innocent others?. Kant calls envy, malice, and ingratitude "the vices of hatred"10. While Aquinas defines envy as a form of sadness, he also sees a strong connection between envy and hatred, in that hatred stems from envy. ${ }^{11}$

\footnotetext{
3 This is the dominant view in popular culture. The issue is more controversial in the academic debate, but many scholars define envy as necessarily malicious (for psychology reviews see Miceli and Castelfranchi 2007, Smith and Kim 2007; for a philosophy review see D'Arms 2017).

4 This view is dominant in both popular and academic contexts (cf. Helm 2013).

5 The association between envy and Schadenfreude has been matter of debate. The most recent evidence suggests that only malicious envy leads to Schadenfreude (cf. van de Ven at al. 2014, which also contains a review of the debate in the psychological literature). Given that most people think of envy only as malicious, such evidence explains the popular association between envy and Schadenfreude.

${ }^{6} \mathrm{I}$ limit my quick review to the "Western" tradition (an imprecise label at best) because it is the one I am most familiar with. Analogous positions can be found in all the other traditions mentioned above.

${ }^{7}$ Passions of the Soul, par. 182 (Descartes 1985, p. 394).

${ }^{8}$ Ethica, def. 23 (emphasis in the original, Spinoza 1949, p. 179.

9 The only difference between malice and envy is that envy is a reaction to a "present enjoyment of another", while malice is "the unprovok'd desire of producing evil to another" Treatise of Human Nature II.2.8 (Hume 1978, p. 377).

10 The Metaphysics of Morals 6:458 (Kant 1996, p. 206).

11 Summa Theologica II-II, Q. 36 (Thomas Aquinas 1947).
} 
Among contemporary philosophers, Rebecca Konyndyk DeYoung explicitly dubs envy "the enemy of love" and claims that "the fundamental attitude of the envious is directly opposed to love. To love is to seek others' good and rejoice when they have it. To envy is to seek to destroy others' good and sorrow over their having it."12

While psychologists have not investigated the relation between love and envy in systematic ways, ${ }^{13}$ there is plenty of evidence that envy correlates negatively with feelings of sympathy and warmth, and positively with hostility and aversion. In light of all these considerations, it is no surprise that clinical psychologists Julie Exline and Anne Zell, in a conceptual inquiry for envy's “antidotes”, suggest that love may be a cure for, or a way of coping with, envy. ${ }^{14}$ If one manages to feel love toward an envied person-they hypothesize - envy will be extinguished, since they cannot coexist.

Thus, there is an overwhelming, cross-cultural and cross-disciplinary, consensus that love and envy are deeply incompatible. This consensus I will challenge in what follows.

\section{2. “But What Do You Mean By...?”: Some Terminology.}

In asking the seemingly simple question "Are love and envy incompatible?", we enter into a multilayered investigation that cannot be fully executed in the limited space of an essay such as this. In this section, I define the central notions of this inquiry.

\footnotetext{
12 Konyndyk DeYoung 2009, p. 51. Most contemporary philosophers concur with Konyndyk DeYoung in considering envy necessarily malicious (and thus immoral). A few defend envy as morally appropriate in some cases (e.g. La Caze 2001, who defends the notion of “righteous envy" - but see Ben-ze'ev 2002 for a critique of it) or at least excusable (e.g. Rawls 1971), or as morally valuable (Thomason 2015). I present my own defense in section 5 .

${ }^{13}$ There are mentions of the relation between the two emotions in the psychological literature but are often brief and speculative. See for instance Fiske 2011, p. 59: "Envy is also likely to undermine friendship. ... A disposition toward envy makes for schadenfreude (glee at the envied other's misfortune), which hardly encourages friendship; responding to a friend's good news with resentment can destroy the relationship."

${ }^{14}$ Exline and Zell 2008, p. 325. The authors maintain that the idea that love is an opposite to envy is crosscultural and cross-religious.
} 
First, what do I mean by love? There are two senses of love that we might be referring to when we ask whether envy is compatible with love: love as a mental state of the person who is said to love, and love as a relationship between two people who love each other.

There are many different theories of love in the first sense: philosophers have thought of love as an emotion, a desire, an appraisal — to mention just a few popular views. ${ }^{15} \mathrm{I}$ wish to remain uncommitted with regard to this issue since it does not appear to bear on our question: no matter how we define its ontological nature, love is always thought, on the one hand, to involve caring for the beloved's wellbeing and rejoicing for their good fortune, and, on the other, to be void of hostility and Schadenfreude.

Furthermore, think of the story of love and envy that we started with. Richard is intensely envious of Ellis, but does not fall out of love because of that; his envy, that is, does not cause him to stop loving Ellis, at least not right away. What is destroyed by Richard's envy for Ellis is their loving relationship. ${ }^{16}$ No matter how Richard's mental states are characterized, the problem seems to be that he cannot be with Ellis: he cannot fulfill the role of a supportive partner who rejoices of her professional success. Indeed, it is clear that he still loves Ellis when he decides to break up with her, because he expresses that love later on. So, while his decision to end the relationship will indirectly and in due course smother his love qua mental state, envy directly and immediately affects his love qua relationship. Of course, the distinction between the two senses of the term is not always easy to draw, and the mental state and the relationship stand in complex relation to one another. Throughout the essay, for simplicity, I will mostly talk of "love" without differentiating between these two senses, unless necessary.

\footnotetext{
15 Again, see Helm 2013.

${ }^{16}$ For some views, such as Kolodny 2003, the distinction between the two senses is minimal, but it is still present.
} 
I will be much more specific when talking about eny. I define envy as an aversive reaction to a perceived disadvantage vis-à-vis a similar other with regard to a domain of self-relevance, which motivates the agent to overcome their disadvantage either by pushing themselves up to the envied person's position or by pulling the envied down to theirs. ${ }^{17}$

In order to understand this long definition, consider Richard's case again. His envy toward Ellis is a painful feeling (aversive reaction) that occurs in response to perceiving Ellis as a more skilled and accomplished surgeon (perceived disadvantage); such a perception stings because Ellis is similar to him in age, status and capability (similar other), and because Richard identifies with being a surgeon (domain of self-relevance); such a painful feeling motivates Richard to overcome his perceived disadvantage: he could either try to become as good as Ellis, or he could try to make her worse off. In fact, he does not quite do either, probably because he is inclined to "level down", but does not want to do something detrimental to Ellis, and so the only solution he sees is to break up with her.

Notice that this definition covers a pretty wide range of envy subtypes. I will describe one of them in detail toward the end of the paper.

The only term that still requires an explanation is incompatibility. Such an explanation, however, requires a section of its own.

\section{The Incompatibility of Love and Envy: Two Versions.}

There are two possible interpretations of the idea that love and envy are incompatible: a descriptive and a normative one. I'll start with the descriptive interpretation, which in turn includes several variations.

\footnotetext{
${ }^{17}$ For a defense of this definition see Protasi 2016a.
} 
First, one could think that love is incompatible with envy in the sense that the phenomenon of loving the beloved is simply impossible: while it might look at if it is, genuine envy, that is, an emotional state that satisfies the definition above, simply cannot arise in the context of an authentic loving relationship, that is, a relationship where people actually love each other, according to any standard view of love. Love and envy are thus contradictory states, like love and not-love.

This interpretation, however, is too strong: we have no reason to look at Richard's behavior and declare either his love or his envy as not genuine. We see him acting as passionate lovers do, and we hear him confessing his envy toward Ellis (and people do not confess their envy lightheartedly, especially toward a beloved, so when they do, we have reason to believe them). Even though Richard's story is fictional, it relies on realistic psychological assumptions, and it succeeds in depicting a possible scenario, which is all we need to refute the impossibility thesis.

Furthermore, notwithstanding a disappointing scarcity of rigorous empirical investigations of this phenomenon, ${ }^{18}$ anecdotal evidence concerning envying the beloved abounds with regard to all forms of love. ${ }^{19}$ The psychoanalytic literature, for instance, features many case studies of envy felt toward (or feared from) parents, children, friends, spouses, or siblings. ${ }^{20}$ There is a wealth of

\footnotetext{
${ }^{18} \mathrm{I}$ am not aware of any empirical research on envy in loving relationships. A related topic that has been investigated is that of ambivalent relationships (see Uchino et al 2001, and Bigelow Bushman and Holt-Lunstad 2009).

${ }^{19} \mathrm{I}$ am not aware of any in-depth philosophical discussion of this issue. Aaron Ben-Ze'ev has a nice post on Psychology Today (Ben-Ze'ev 2009). Krista Thomason briefly argues for the possibility of envy toward loved ones (esp. "friends, siblings, parents, and colleagues", p. 45), in Thomason 2015.

${ }^{20}$ Cf. Stein 1990, Ellman 2000, Harris 2002, Polledri 2003, LaVerde-Rubio 2004, Anastasopoulos 2007, Gerhardt 2009, Zeavin 2012. The epistemological limits of psychoanalysis are notorious, even though some authors have recently suggested that psychoanalysis could become, and is on its way to becoming, a science (see Lacewing 2013). However, I am not using psychoanalytic research as a source of scientific evidence, but rather as a source of narratives that are akin to fictional examples or thought experiments in presenting nuanced and compelling pictures of human experience. For a defense of the thesis (which I do not endorse here) that psychoanalytic theory pursues the same inquiry as philosophical moral psychology, see Harcourt 2013. For a non-psychoanalytic, epidemiological perspective on sibling relationships, which includes a discussion of envy, see Dunn and Kendrick 1982.
} 
self-help books on the topic, ${ }^{21}$ and the internet is replete with articles on how to deal with either being envied by or feeling envy toward friends and other loved ones. The existence and popularity of such advice is indirect evidence that it is possible to envy the beloved.

A more plausible version of the descriptive interpretation of the incompatibility assumption is the one that I have implicitly adopted in much of my initial discussion: envy kills love after it has already bloomed. If one finds oneself in the grip of intense envy toward the beloved, as in Richard's case, their love will unavoidably wilt, for instance because envy wounds the lover's self-esteem, provoking resentment instead of support or joy for the beloved's success. ${ }^{22}$ According to this view, love and envy are like light and darkness: the more envy there is, the less love there can be, and vice versa. They are opposite, rather than contradictory, states.

This view seems more promising. However, this interpretation might be too weak. Opposite emotional states, such as sadness and joy, are compatible in the sense that one can feel a mixture of both, and the resulting state may be stable and even desirable (think of melancholia). But the alleged incompatibility between love and envy seems to imply its mixture would not be stable or desirable.

In other words, those who think of love and envy as incompatible in the way that I am trying to capture, consider envy to be a pollutant: even a tiny bit in a clear puddle of water will make the water undrinkable. ${ }^{23}$

However, if interpreted descriptively, this view is once again too strong. Most people

\footnotetext{
21 See, for instance, Cohen 1987, and Shapiro Barash 2007, among many others.

22 Vice versa, if one comes to love an envied person, one's envy is supposed to fade away. On the surface, this second case seems highly implausible, but that is after all what the idea of love as an "antidote" to envy is supposed to mean.

${ }^{23}$ Conversely love is like a balsam that heals all wounds: if you manage to love the envied, you will stop envying them, as in Exline and Zell's hypothesis, mentioned in the previous section. Notice that one might be skeptical that there is a perfect symmetry here: it is much easier to spoil something good, than to fix something bad.
} 
would agree that a loving relationship can tolerate occasional and short-lived bouts of envy, in the same way as it can tolerate other negative emotions, including hatred. ${ }^{24}$

The only plausible interpretation of the incompatibility between love and envy is thus normative: they cannot coexist in their ideal forms. In particular, true love should be void of envy proper. This is the thesis that I am going to argue against in the remainder of the paper.

I do so in two stages. I first propose an indirect argument. Because love and envy both thrive in the same psychological conditions, it is not unlikely to feel envy toward the beloved. If we want ideals that do not go against our psychological propensities, then we should not aim for a love that is wholly void of envy. I will articulate this argument in the next section.

I then propose a direct argument, which aims to show that love can even benefit from envy. I draw on my own original taxonomy of envy to argue that a certain variety of envy, emulative envy, is not only not detrimental to love, but it can even benefit it.

\section{Comparison, Similarity and Desire for Esteem: Where Love and Envy Thrive.}

Imagine a beautiful ornamental plant that grows well in a soil with a certain composition. ${ }^{25}$ Now imagine a weed that grows in the same kind of soil. Whenever the gardener tries to get rid of the weed by changing the composition of the soil, the weed grows stunted or stops growing altogether, but so does the plant she is trying to cultivate. If the gardener aims for a garden completely void of weeds, she is destined to be constantly frustrated. But if she accepts the presence of weeds, she will get to enjoy the beautiful plant as well.

\footnotetext{
24 Thank you to a reviewer that pointed this out to me.

25 Any person who has actual gardening knowledge will immediately realize I have none. Please take the analogy with a grain of charity.
} 
I submit that love_-you guessed it—is like the plant, and envy is like the weed. The soil is human nature. It is not possible to get rid of envy without getting rid of psychological and social mechanisms that favor the arousal of love as well, at least at the level of the species. The reason lies in the crucial role of social comparison in human psychology.

Empirical evidence shows that, while there are individual differences in how frequently and intensely people compares themselves to others, we all do it to a larger extent than we might realize. As social psychologist Susan Fiske puts it, "we are comparison machines". ${ }^{26}$

Social comparison is a process that fulfills three functions.

First, social comparison informs us about where we stand and how we stack unto others with regard to pretty much anything, from our abilities and opinions to facts such as how healthy we are $;^{27}$ when the comparison is upward, that is, to our disadvantage, it may motivate us to selfimprove. Second, when the comparison is downward, that is, to your advantage, it protects our self-esteem and makes us feel good. Third, comparison helps us fit into our social groups.

As I mentioned earlier, some individuals are more prone to social comparison than others. Relevantly for our investigation, those who score higher on the Social Comparison Orientation Scale (SCO) "tend to think about themselves a lot, but they also tend to think about others a lot" ${ }^{\prime 28}$; they are very self-focused and self-concerned, but they are also more emphatic and sensitive to the needs and perspectives of others. From an inclination to social comparison, then, stem both prosocial attitudes such as empathy, sensitivity, feeling connected with others, and antisocial attitudes such as competition, envy, scorn, shame.

\footnotetext{
${ }^{26}$ Fiske 2011, p. 13.

${ }^{27}$ Fiske 2011, p. 81.

${ }^{28}$ Fiske 2011, p. 57.
} 
These are deep psychological mechanisms that we are unlikely to eliminate from our nature any time soon. We are prone to comparisons. But the most salient comparisons are those to similar others: those are the ones that are most likely to occur, and also the ones that are most diagnostic and significant for our self-assessment. It is this kind of comparison that is necessary to feel envy.

\subsection{The Role of Similarity in Envy and Love}

That similarity to the envied is a necessary condition for envy to arise is one of the most established and uncontroversial findings in the psychological literature: we do not feel envy toward people whom we do not perceive as similar to us along some relevant and salient dimension. ${ }^{29}$

Psychologists generally do not spell out this factor to the level of detail that would satisfy a philosopher, and one of the reasons is that what counts as "similar" is heavily context-dependent. The relevant similarity may be based on gender, sex, age, or some other general category. For instance, when we envy someone for their athletic fitness, age and gender are relevant and salient features, while more specific personal features may be unimportant. But in other contexts being similar means sharing the same level of skills and interests, such as two surgeons who work in the same field and compete for the same award.

Aristotle, a great psychologist ante litteram, foresaw this finding in the Rhetoric: we feel [envy] towards our equals; ... and by 'equals' I mean equals in birth, relationship, age, disposition, distinction, or wealth. ... We envy those who are near us in time, place, age, or reputation. Hence the line 'Ay, kin can even be jealous of their kin.' Also our fellow-competitors, who are indeed the people just mentioned-we do not compete with men who lived a hundred centuries ago, or those not yet born, or those who dwell near the Pillars of Hercules, or those whom, in our opinion or that of others, we take to be far below us or far above us. So too we compete with those who follow the same ends as ourselves: we compete with our rivals in sport or in love, and generally with those who are after the same things; and it is therefore these whom we are bound to envy beyond all others. Hence the saying, Potter against potter. We also envy those whose possession of or success in a thing is a reproach to us: these are our neighbours and

\footnotetext{
${ }^{29}$ See Miceli and Castelfranchi 2007, pp. 453-456, and Smith and Kim 2007, p. 50; see also Protasi $2016 a$, p. 3.
} 
equals; for it is clear that it is our own fault we have missed the good thing in question; this annoys us, and excites envy in us (Rhetoric, II.10).

Aristotle thus lists many kinds of similarity: equality of reputation and social status, spatiotemporal proximity, commonality of background, equivalence of competences and skills, and affinity of goals and values. ${ }^{30}$

Interestingly enough, these are almost exactly the same kinds of equality, closeness and likeness that he discusses in Nicomachean Ethics when talking about philia, that is, the loving relationship that can arise between husband and wife, between father and son, between brothers, between comrades, between erotic lovers. "Now equality and likeness are philia," 32 he claims, and indeed he devotes a large part of the book to explain the several ways in which philoi can be equal or similar.

Here too, Aristotle's intuition has found empirical confirmation. There is extensive evidence that "when people have a choice, they choose relationships with people who are similar to them. ${ }^{\text {33 }}$ Contrary to the popular dictum, it is similars— not opposites— that attract. ${ }^{34}$

Thus, similarity in its various manifestations is a necessary condition for both love and envy. Both attitudes are ultimately dependent on the tendency and ability that human beings have to compare themselves to others, which is a fundamental, multifunctional component of human

\footnotetext{
30 Aristotle is not the only historical figure to discuss the role of similarity in envy. Other philosophers, such as Basil of Caesarea, Bacon, and Hume, also remark extensively on it (Basil 1950, Bacon 1999, Hume 1978).

31 Philia also describes the relationship between business partners and fellow citizens, which shows how much broader the Greek notion of philia is, compared to our modern notion of love.

${ }^{32}$ Cf. Nicomachean Ethics, VIII. 8, and cf. also VIII.5. The quote is from W. D. Ross' translation.

${ }^{33}$ Bahns et al 2012, p. 120.

${ }^{34}$ At least, not in most cases. The empirical literature on similarity in personal relations is too vast for me to delve into it here, but one complication worth mentioning is that people may perceive each other as similar, even when they are not. Another one is that there are many dimensions along which an interpersonal interaction develops and is considered satisfactory. See Dryer and Horwitz 1997 for evidence that in some instances actual complementarity along the control dimension (i.e. submissive vs. dominant attitudes) predicts satisfactory interactions, provided that similarity along other dimensions (such as affiliation) is preserved.
} 
psychology. But there is one more tile to be added to the increasingly complicated mosaic of love and envy, pace Giotto.

\subsection{The Role of Esteem in Love and Envy}

Social comparison favors the arousal of love and envy in at least another way, which is highlighted in Jean-Jacques Rousseau's Second Discourse, in a passage that describes the (hypothetical) genealogy

of human society:

Among young people of opposite sexes, living in neighbouring huts, the transient commerce required by nature soon led, through mutual intercourse, to another kind not less agreeable, and more permanent. Men began now to take the difference between objects into account, and to make comparisons; they acquired imperceptibly the ideas of beauty and merit, which soon gave rise to feelings of preference. In consequence of seeing each other often, they could not do without seeing each other constantly. A tender and pleasant feeling insinuated itself into their souls, and the least opposition turned it into an impetuous fury: with love arose jealousy; 35 discord triumphed, and human blood was sacrificed to the gentlest of all passions.

As ideas and feelings succeeded one another, and heart and head were brought into play, men continued to lay aside their original wildness; their private connections became every day more intimate as their limits extended. They accustomed themselves to assemble before their huts round a large tree; singing and dancing, the true offspring of love and leisure, became the amusement, or rather the occupation, of men and women thus assembled together with nothing else to do. Each one began to consider the rest, and to wish to be considered in turn; and thus a value came to be attached to public esteem. Whoever sang or danced best, whoever was the handsomest, the strongest, the most dexterous, or the most eloquent, came to be of most consideration; and this was the first step towards inequality, and at the same time towards vice. From these first distinctions arose on the one side vanity and contempt and on the other shame and envy: and the fermentation caused by these new leavens ended by producing combinations fatal to innocence and happiness. ${ }^{36}$

Rousseau's initial remarks are on physical proximity, but he then goes on to discuss the psychological mechanisms by which such a proximity produces both prosocial and antisocial feelings. ${ }^{37}$ When human beings compare themselves to others, they start to value public esteem,

\footnotetext{
35 Since in French, jalousie can be used to refer to envie as well, it is not clear if Rousseau means romantic jealousy, envy or a combination of both (which seems to me the most plausible interpretation). In any case, he explicitly mentions envy at the end of the quoted passage.

36 A Discourse on the Origin of Inequality, II, cf. Rousseau 2005, pp. 68-69, emphases mine.

${ }^{37}$ Remember how the evidence concerning high-SCO people shows that there is a connection between being prone to social comparison, being disposed to envy and being empathic.
} 
which is inherently comparative. Our estimable qualities make us appropriate potential recipients of either love or envy. Whether we are loved or envied, we come to perceive ourselves as having valuable traits that make us better than at least some similar others (who are our competitors, in love or other domains). Whether we love or envy, we look at the person who has those valuable traits, and we are drawn to them, either to enjoy those qualities in and with our lovers, or to get them for ourselves.

Love and envy, then, not only both require some sort of similarity, but also both involve seeing another person as uniquely valuable. Such a perception can conflict with the agent's own desire for public esteem, for standing out in a crowd as the coolest individual, she who is most lovable, but also most enviable.

\subsection{Examples}

Let us go back to our lovers, Richard and Ellis, and apply to their case these ideas.

Richard and Ellis share a social position: they are both at the margin of the profession, different from the majority of their peers, who are White men. They are obviously close in space and time. They are equally talented (well, Ellis might be just a little more talented!) and they share the same goal and ambition: to become an excellent surgeon. These are the features that allow Richard to realize that he compares unfavorably to Ellis, and to feel the pangs of envy.

But these are also the features that ground his love for her! Richard and Ellis have fallen in love with each other, despite the fact that they are both already married, because they perceive themselves as soul mates: they strive for the same objectives, enjoy the same activities, thrive in the same challenges. Their spouses, on the other hand, do not understand their passion, and do not know what it means to save lives in the ER and discover exciting surgical techniques.

Furthermore, remember what triggers Richard's envy: that Ellis might win a prestigious prize, a tangible token of public esteem, that he was also in the run for. We can imagine that Ellis' 
estimable qualities made her stand out in the crowd of residents, rendering her attractive and desirable to Richard, who was also proud to have won her love. But once they become competitors, those lovable qualities also become enviable qualities. Ellis is the most prominent resident—Richard is not.

So far, I have discussed only a case of romantic love. But what about other kinds of love? Different kinds of similarity, proximity, equality and affinity will be responsible for the arousal of envy and love, and estimable qualities will play different roles in different kinds of love.

Consider friendship first. Friendships often develop on the basis of similarity of a sort or other: our childhood friends are often those we happened to share a neighborhood or school with; later, we choose friends on the basis of affinity of interests or character; even later, friendships arise from sharing a workplace, or because our children go to the same schools. In all these cases, perceived and salient similarities between us and our friends will make the arousal of envy likely: their toys or houses are bigger; their grades or salaries higher; their spouses more attractive or their children more obedient; they are more successful in their job or appear to be happier.

Sibling love is notoriously prone to rivalrous emotions such as envy and jealousy. Constant comparisons, made by siblings themselves, parents or anybody else, explain the envy component of sibling rivalry, which is likely to be exacerbated by closeness in age, gender and other salient identity characteristics.

Sibling love is very similar to friendly love, except that we do not choose our siblings as we choose our friends. However, both loves are characterized by a peer relationship, and by sharing a background, or activities, or values and goals (where the disjunction is obviously inclusive). In fact, Aristotle devotes particular attention to both loves and their different dimensions of similarity and equality. 
Finally, even love between parents and children is characterized by certain kinds of similarities: whether genetically inherited or acquired through time, parents and children share many character features, values and interests as well. Anecdotal evidence suggests that, the more similar parents and children are, the more likely they will be to develop feelings of competition and envy. A typical case is the one, often represented in fictions, of parents who compare their children to their younger selves, and resent the children's greater fortune or success. ${ }^{38}$

Those familiar with the philosophical literature on love might wonder whether I am implicitly relying on the idea that love is grounded — that is, rendered appropriate or justified —in the beloved's personal qualities. While I am myself a defender of that view, ${ }^{39} \mathrm{I}$ do not think such a commitment is required for the view I am presenting here, because I am not discussing normative reasons at all. What reasons Richard has to love Ellis, I do not know. I am looking at Richard's love, and at the role estimable qualities have, from a purely psychological perspective.

Suppose that there are no justificatory reasons for love. It is still the case that he comes to appreciate her estimable qualities by loving her. Or consider familial love, which for most authors is grounded in the fact that there is a relationship between the parties: the justificatory reason I love my daughter is that she is my daughter. That does not bear on the fact that me I appreciate her many qualities, I am proud of her for them and I might come to envy her because of them. ${ }^{40}$

\subsection{Qualifications}

My thesis does not imply that envy is bound to occur in every loving relationship. There are many ways of loving and many ways of perceiving the beloved. Some loving relationships are less based on equality and similarity than others. A romantic relationship where partners see themselves as

\footnotetext{
38 See Ben-ze'ev 2009.

39 See Protasi 2016b.

40 Thank you to an anonymous reviewer for prompting me to address this potential objection.
} 
occupying unequal roles, for instance, as it was common in the past, will not likely see the arousal of envy. Similarly, when partners value different things, or excel in different domains, they will also be less prone to envying each other. ${ }^{41}$ However, remember that evidence shows that stable and satisfying relationships occur between people who share values and interests. Furthermore, romantic relationships are increasingly based on equality, so one would expect an increase in occasions for feeling envy as well.

Another way in which romantic partners might avoid envy is by identifying with each other very strongly. Instead of experiencing a process of comparison, they will thus experience a process that psychologists call reflection: the other person's success makes the agent "bask in reflected glory". "Comparison" and "reflection" are here meant as technical terms designating different outcomes stemming from the same kind of upward social comparison. ${ }^{43}$ I discussed earlier the many roles of social comparison: reflection, differently from comparison, is not diagnostic and informative of our position, but protective of our self-esteem. Basking in the beloved's success is a common experience, but for the aforementioned reasons it is not always possible. Furthermore, there are downsides to completely identifying with another person, which however I cannot discuss here. ${ }^{44}$

As to other forms of love, while friendship and sibling love might be the most prone to competition and rivalry and thus envy, there are exceptions there too, which may be the result of

\footnotetext{
41 Thank you to an anonymous reviewer for pointing out this possibility to me.

42 Cialdini et al 1976.

43 Tesser and Collins 1988.

${ }^{44}$ One could object that in love a full-fledged identification with the beloved is always supposed to happen, and therefore the very arousal of envy is evidence that love is not genuine or authentic. After all, some theorists define love precisely as the creation of, and desire for, complete union with another person (see Helm 2013). Such a view, both in its descriptive and normative versions, has many advocates but also many opponents; I am, perhaps unsurprisingly, in the latter group, but I cannot defend my position here. So I will just offer the following qualification: if people experience their love as complete union, then they will be unlikely to experience envy toward one another. I thank an anonymous reviewer for the objection.
} 
conscious choices: one might purposefully avoid engaging in activities that one's older siblings excel at, or one might choose friends that excel at things that one does not care about. ${ }^{45}$

Finally, consider parents-children love. In parental love envy is less likely when parents see their children as either an extension of themselves, or as very different from themselves; in filial love young children tend to see their parents as role model to emulate and, if the dissimilarity with them is salient, they will feel admiration and pride. And yet, again, we have much anecdotal evidence that both parents and children do feel envy toward one another, and that is especially likely when children grow older and the similarities between them increase.

In sum, many factors are responsible for the intensity and amount of envy individuals feel. The purpose of this section was to articulate a general principle: that the co-occurrence of love and envy is rendered more likely, at the level of the species, by the fact that they thrive in the same psychological conditions.

\subsection{Indirect Argument}

Here is finally my indirect argument in favor of the normative compatibility of love and envy. 1. Envy for the beloved is an ingrained psychological propensity.

2. We should not endorse normative ideals that go against ingrained psychological propensities.

3. The ideal of love without any envy goes against an ingrained psychological propensity.

Therefore, we should not endorse the ideal of love without any envy.

I have argued in favor of premise one throughout this section, and I take premise three to be a mere corollary of premise one. I will not give any argument for the second premise, since it is a version of the widespread notion that "ought implies can", a principle whose defense goes well beyond the scope of this paper. ${ }^{46}$

\footnotetext{
45 This might be a self-care strategy for people who score high on the Social Comparison Orientation Scale.

${ }^{46}$ Cf. Rawls 1971 for a similar approach to mine.
} 
I do, however, want to briefly comment on two reasons why we should not endorse this ideal of envy-less love in particular. I think the ideal is both self-defeating and too demanding.

In order to see the first aspect, recall what Richard did when he realized he was very envious of Ellis: he broke up with her. The strategy of interrupting the relationship when it becomes "toxic", as it is often represented in self-help columns, is not only costly, but fundamentally misguided, because it does not take into account how the co-occurrence of love and envy is likely to repeat itself. Richard, in particular, is bound to find himself in the same situation, given the kind of person he is (a driven competitive surgeon) and the kind of persons he is attracted to (similarly driven and competitive surgeons), and given his interests and values. ${ }^{47}$

As for the demandingness aspect, a natural objection to premise two is that ethics is supposed to be demanding and difficult, and that moral agents are expected to struggle and fail. Even if we never hit the target, we should keep aiming at it, as Aristotle recommends. ${ }^{48}$ Remember the metaphor of the flower and the weed: those who are comfortable with ethics' demandingness would say that, even if flowers and seed thrive in the same soil, that in itself is no reason to let the weed grow undisturbed: the scrupulous gardener will keep pulling it indefatigably.

Correspondingly, we should keep uprooting envy from our loves, no matter how many times we have to do it, and even at the cost of terminating every relationship that involves envy. Perhaps Richard should learn to love different women; perhaps we should always look for friends whom we can admire but cannot envy; perhaps we should pursue loving relationships based on unequal roles or different interests and values.

It is in response to this approach that I present my final direct argument.

\footnotetext{
${ }^{47}$ In fact, in the TV show that I am referring to, he does later fall in love with another brilliant ambitious woman, named Catherine Avery, toward whom at times he feels inferior, and thus envious.

${ }^{48}$ Cf. Nicomachean Ethics 1094a18-22.
} 


\section{In Praise of Envying the Beloved.}

In this final section, I am going to argue that a certain kind of envy—emulative envy—can be beneficial to the loving relationship; in turn, a certain kind of love-wise love-can be beneficial to our lives. Thus, that love and envy are so linked in our psychology is not something that we should merely tolerate, but also positively embrace.

\section{1 Emulative Envy}

Envy comes in many varieties, which vary in internal psychological structure, behavioral manifestations, and moral and prudential value. I articulate in detail my own taxonomy elsewhere. ${ }^{49}$ Here I can only sketch the profile of the kind of envy that can be beneficial to love: emulative envy.

Emulative envy is an aversive reaction to a perceived disadvantage vis-à-vis a similar other with regard to a domain of self-importance, which motivates the agent to overcome their disadvantage by improving themselves. Its focus of concern is the lack of the envied good (as opposed to the fact that someone else has it) and it involves a perception that attaining the good for oneself is possible (as opposed to not possible).

Let me stress again the three features that make emulative envy different from other kinds of envy: it is focused on the lacked good; it perceives improvement as possible; it thus motivates the agent to self-improve. As a consequence of these features, the emulative envier looks at the envied not as someone to deprive of desirable and valuable qualities or goods, but as a representation of what the agent herself could be or have.

Emulative envy is still an unpleasant emotion, since, like any kind of envy, it necessarily involves the perception of lacking something important and valuable that is possessed by a similar

\footnotetext{
${ }^{49}$ Protasi 2016a.
} 
other. But in the context of love this pain is counteracted by the consolation that this similar other is the beloved. Furthermore, emulative envy is a forward-looking, optimistic and hopeful attitude, insofar as it involves, by definition, perception that one is capable of future improvements.

Most importantly, however, because of its focus on the lacked good and the belief that it is attainable, emulative envy cannot be satisfied by "leveling down", that is, by bringing down the envied to one's inferior position. It is thus void of malice or ill will, which are components of other varieties of envy, and is therefore fully compatible with the duties of benevolence that love, in its best manifestations, prescribes.

A common objection to emulative envy is that it is not envy proper. Such an objection is often based on linguistic intuitions and culturally-relative practices: speakers of Dutch, Thai, and Polish, for instance, use two terms to refer to emotions that in English would be both translated as "envy", and that are characterized by either the motivational tendency to "level up" or to "level down". Both philosophers and psychologists have argued in favor of some sort of "benign envy", so my position is not unique, and is supported by a growing corpus of empirical evidence. ${ }^{50}$

A similar objection is that emulative envy is a form of admiration. But the two emotions are quite different: for one, admiration is pleasant, while emulative envy is unpleasant. Their different affect stems from the different relation to the self, whose nature Kierkegaard expressed in one pithy sentence: "admiration is happy self-surrender; envy is unhappy self-assertion". ${ }^{51}$ In other words, admiration is similar to awe: we admire a person like we admire a landscape. Thus, we might be motivated to protect it, but not to become like it. Furthermore, the admired person's comparative superiority is not the salient element,

${ }^{50}$ For two philosophical accounts see Rawls 1971 p. 467, and Taylor 1988 and 2006. For a review of the empirical evidence supporting the distinction between subtypes of envy and in particular the existence of benign envy, see van de Ven 2016.

${ }^{51}$ Kierkegaard 1941, p. 139. 
because their talents and accomplishments are far beyond our reach, either because of a gap in ability, or because of a difference in interest. ${ }^{52}$ So, for instance, Richard might admire, not envy, the Chief of Surgery, who is much more experienced than him.

It might now be suggested that, precisely in virtue of these differences, admiration is the nobler alternative to emulative envy. When we compare to our beloved, we should strive to feel admiration, not envy.

But, while admiration is a good emotion to feel toward a beloved, it cannot fully substitute emulative envy, for two reasons. First, because it may be less conducive to an agent's self-improvement. Envy's negative affect may be more effective in motivating the agent to do the hard work required to better oneself. ${ }^{53}$ Second, and more decisively, whether or not we feel admiration or envy is not fully up to us. Admiration and emulative envy are different emotions that are characterized by different situational antecedents. Richard falls in love with Ellis, rather than the Chief of Surgery, because Ellis is like him; what makes him attracted to Ellis in the first place is precisely the fact that they are similar and equal at many levels. In the case of loves that are more unequal, it might be easier to bring oneself to develop admiration, but there are limits there too: if envy arises in the first place, it is because of perceived similarity: we can make that similarity less salient, but we cannot eliminate it altogether. In general, manipulating our emotional experience is possible, but some shifts are easier than others: for instance, it is probably easier to move from one

\footnotetext{
52 See Miceli and Castelfranchi 2007 for a psychological perspective on these differences, and Thomason 2015 for a nice philosophical analysis of the same issues (different scope and difference salience of the self).

53 The empirical evidence currently available is mixed, with some studies (Van de Ven et al. 2011) showing that admiration does not lead to self-improve while benign envy does, and others (Schindler et al. 2015) showing that admiration does motivate to self-improve. Van de Ven 2015 suggests that emulative envy is more conducive to self-improvement in the short term, while admiration might motivate to self-improve down the line, but given the limited amount of research on this topic, we do not have conclusive evidence.
} 
subtype of envy to another, than to move from envy to admiration (even harder would be to move to scorn or pity).

In fact, the final objection is that one might not be able to feel emulative envy either: after all, that's where Richard found himself. That is, the agent might not be in a condition that allows them to feel emulative envy as opposed to other, more pernicious, kinds of envy. For instance, the envied good may be exclusive such that only one person can have it. I believe that this possibility is less frequent than it might seem: the majority of genuine goods are not exclusive, even when we perceive them as such. ${ }^{54}$ Part of what is involved in emulative envy is the capacity to discriminate between actual and illusory goods, and between exclusive and non-exclusive goods. But there are some unfortunate cases, especially those that involve positional or zero-sum goods: for instance, two friends or romantic partners might compete for the exact same job; a father and a son might both want to be the person who earns the most in the family; two twins might strive for being valedictorian, or the coolest kid, at the same high school. In all these cases, bringing oneself to feel emulative envy with regard to this specific good would in fact not be possible.

Here we face a real limitation. Sadly, emulative envy is but one form of envy. Other forms can arise — as we have seen in Richard's case — and that is truly problematic for the loving relationship. ${ }^{55}$ This is where the second ideal I advocate comes in.

\section{2 Wise Love}

I provided a precise definition of emulative envy, which is a specific emotional phenomenon. I will not attempt to provide any such definition for wise love, because I do not think it is possible,

\footnotetext{
54 Envy might be inappropriate, that is, based on either a misperception of one's disadvantage or on the actual value of the (allegedly) lacked good, but for simplicity I talk here as if it is always appropriate.

${ }^{55}$ Notice, however, that Richard could have reminded himself that he could have got the award the next year: it was possible for him to feel emulative envy, even though he did not realize it.
} 
much like it would be hard to provide a substantive and at the same time satisfying definition of virtue: ${ }^{56}$ some ideals can only be alluded to, or pointed at.

I use "wise" because the lover that I have in mind is a practically wise one. ${ }^{57} \mathrm{Wise}$ love involves the cultivation, even if not the full achievement, of ethical virtues such as compassion and thoughtfulness, and of intellectual virtues such as unbiased self-reflection. ${ }^{58}$ The wise lover is committed to protecting the loving relationship and making it flourish notwithstanding and sometimes in virtue of negative, aggressive emotions that may arise. That commitment implies that the lover may encourage the beloved to feel emulative envy toward her. Envy can be an opportunity for growth, both for the relationship and the lovers.

When it is not emulative, loving wisely implies becoming capable of forgiving and forgetting, of understanding that the beloved is human and thus prone to human psychological propensities such as envy. Two caveats: first, that wise love as an ideal accepts the human propensity to envy does not mean that individual, actual wise lovers need to have the philosophical and psychological knowledge described in section 4! An intuitive understanding of it will suffice. Second, that wise lovers forgive and forget envy does not mean that they should forgive and forget each and every occurrence of envy: some envious actions or expressions are deleterious and immoral and should not be tolerated. Likewise, a wise lover might decide to part sides with a beloved who is disposed to intense malicious envy: no love relationship benefits from that, and no

\footnotetext{
56 The Aristotelian definition of virtue as a mean is notoriously unsatisfying, and meant to be combined with personal acquaintance with virtue itself.

${ }^{57}$ I thank Aaron Ben-ze'ev for suggesting the label "profound love." I settled on "wise" for the broadly Aristotelian connotation.

58 In an Aristotelian account, the best kind of philia is the one based on excellence (arête), which may be the only good that is uncontroversially noncomparative; furthermore, if both lovers are phronimoi (that is, completely practically virtuous) they might be presumed to never feel envy. It might thus seem inconsistent to suggest that an Aristotelian account of good love can include a vice. But my notion of emulative envy is very close to Aristotelian zelos, which is defined as a noble emotion in the Rhetoric and which is opposite to the vice of phthonos (see Protasi 2016a for a defense). Furthermore, my account is meant to be Aristotelian in spirit, but in spirit only. I do not wish to commit to a specific account of love, nor to a specific normative ethics. I thank a reviewer for prompting me to clarify this point.
} 
lover should tolerate that. But to a large extent what counts as intense or intolerable is an

idiosyncratic matter, and part of the wisdom required by wise love involves precisely being able to assess this matter correctly.

When envy is emulative, loving wisely takes rivalry and competition as a chance for shared, genuine improvement, and reciprocal, altruistic support. While Richard has not experienced emulative envy with Ellis, he does in his subsequent relationship with another ambitious and brilliant surgeon, Catherine. ${ }^{59}$ With Catherine, he starts to learn that envy is part of the cost of loving women like Catherine and Ellis, and his love grows a little wiser.

Once again, different forms of love will be wise in different ways. In particular, they may require different ways of managing envy. For instance, parents are expected to be role models for their children, provided they do so without excessive paternalism, and so it is appropriate for them to adopt an explicitly pedagogic attitude in dealing with their children's envy. For children it is less appropriate or feasible to do so, and so they might find it more fitting and helpful to adopt a nurturing and compassionate attitude toward their parent's envy. Sibling relationships can tolerate more open competitiveness than others, and so envy might be dealt with in the spirit of fair and affectionate competition. Similarly with some kinds of friendships: some friendships will tolerate a higher degree of rivalry and competitiveness than others.

\subsection{An Exemplary Love Story: My Brilliant Friend}

Wise love cannot be defined, but perhaps it can be pointed at. So far I have liberally drawn narratives from a well-written and well-acted TV show. I now move to the more traditional practice of using literary examples. This description can be taken as my final argument. ${ }^{60}$

\footnotetext{
${ }^{59}$ Cf. Grey's Anatomy, season 8, ep. 5 and ff.

${ }^{60}$ Many philosophers use extended discussion of fictional examples, literary ones in particular, to make philosophical arguments. Martha Nussbaum is one of the most prominent ones, and she defends such a practice in Nussbaum 1990.
} 
Elena Ferrante has been acclaimed internationally as the most important Italian writer of her generation. She is best known abroad for a series of four novels, whose first volume is titled My Brilliant Friend, recounting the lifetime friendship between two Neapolitan women.

The complex story of Lenù and Lila, and of the multitude of side characters, unfolds over almost two thousand pages, so I will not attempt to summarize it here. But envy is all over their, and other characters', relationship. ${ }^{61}$ Lenù is the narrative voice and she often talks of the envy she feels for Lila, and the envy that in turn she perceives coming from her best friend. The very title of the first novel is ambiguous: until the end, it is not clear who "the brilliant friend" is supposed to be. Often, given that it is Lenù who is writing and talking about how much she admires Lila, we tend to think that the brilliant friend is Lila, the amazingly gifted and charming woman capable of overcoming poverty, loss, and physical and emotional abuse of every kind. But at times we see that in fact it is Lila who thinks of Lenù as the brilliant one, the one who thanks to hard work, determination and strenuous self-discipline made it out of the degraded working-class neighborhood the two friends grew up in. The crowd of secondary and tertiary characters also give discordant verdicts, praising and admiring now one, now the other.

By the end of the tetralogy, the reader realizes that they both are the brilliant friend—-that that is precisely the point, that that is why the story is so compelling and their friendship so durable, notwithstanding the many adversities, tensions, fractures it goes through. They are both extraordinary persons who manage to live lives far more meaningful, far richer than those of their neighborhood counterparts.

Neither woman could have achieved such a result without the other. From the very start, when they are little girls in primary school, Lila and Lenù prod and stimulate each other to do

\footnotetext{
${ }^{61}$ Envy also characterizes the relation Lenù has with her mother, among other negative emotions, but their relationship is far from ideal, and the envy present in it is not emulative.
} 
better, and they never stop. They will compete throughout their lives not just on the professional terrain, but also on the romantic one, unwittingly and resentfully sharing lovers and suitors. Their competition is often implicit and unconfessed, but fierce and obvious, and sometimes ugly and petty. Their rivalry leads Lenù, whose thoughts we are more privy to than Lila's, to wish that her friend died, and in turn to believe that the envy she perceives from Lila has cursed her own happiness, as in the superstitious notion of the "evil eye". ${ }^{62}$

Thus, their relationship seems to experience all varieties of envy, even the most spiteful kind. And yet, they also experience the most noble kind, the one that constantly moves them to self-improve. It is a recurring theme of the books that neither friend would be who she is without the other as a model and as a rival. Their deep, intense, passionate friendship, which is for both the most constant and enduring love in their lives, is wise: it knows that envy is the dark side of love, and that love can illuminate, but not annihilate, envy. ${ }^{63}$

\footnotetext{
${ }^{62}$ Many peasant and tribal societies share the superstition of the evil eye, a destructive power emanatingusually involuntarily_from the look of an envious person (Foster 1972, Lindholm 2008).

63 This paper has long been in the making and has benefited from the feedback of many, many people, among which: Aaron Ben-ze'ev, Justin Clardy, Pamela Corcoran, Stephen Darwall, Jamie Dow, Tamar Szabó Gendler, June Gruber, Verity Harte, Jasper Heaton, Hud Hudson, Carrie Ichikawa Jenkins, Jonathan Jenkins Ichikawa, Michael Lacewing, Gerald Lang, Shen-yi Liao, Dominic McIver Lopes, Heather Logue, Nicholas Martin, Aaron Meskin, Donnchadh O’Conaill, Regina Rini, Aida Roige Mas, Matthew Smith, Zoltán Gendler Szabó, Neal Tognazzini, Pekka Väyrynen, Matthew Walker, Dennis Whitcomb, Justin Weinberg, more anonymous reviewers than I care to count, and audience members at University of Leeds and EPSSE Annual Conference at University of Edinburgh. I am thankful to all of you, and I apologize if I forgot anyone.
} 


\section{References}

Anastasopoulos, D. 2007, “The narcissism of depression or the depression of narcissism and adolescence," Journal Of Child Psychotherapy, 33(3): 345-362.

Aristotle 2004, Rhetoric, tr. by W. Rhys Roberts, New York: Dover Thrift Editions.

Bacon, F. 1999, The Essays, Or Counsels Civil and Moral (1625), ed. by Vickers, B., New York: Oxford University Press.

Bahns, A.J., Pickett, K. M., Crandall, C. S. 2012, “Social ecology of similarity: Big schools, small schools and social relationships", Group Processes and Intergroup Relations, 15(1): $119-131$.

Basil of Caesarea 1950, Ascetical Works, tr. by Wagner, M. M., Washington, DC: The Catholic University of America Press, 463-474.

Ben-Ze’ev, A. 2002, “Are Envy, Anger, and Resentment Moral Emotions?”, Philosophical Explorations: An International Journal for the Philosophy of Mind and Action, 5(2):148-154.

Ben-Ze’ev, A. 2009, “Darling, Do You Envy Our Son as Much as I Envy Our Daughter?” https://www.psychologytoday.com/blog/in-the-name-love/200904/darling-do-

\section{you-envy-our-son-much-i-envy-our-daughter}

Bigelow Bushman, B. and Holt-Lunstad, J. 2009, “Understanding Social Relationship Maintenance Among Friends: Why we don't end those frustrating friendships," Journal of Social and Clinical Psychology, 28(6): 749-778.

Cialdini, R. B., Borden, R. J., Thorne, A., Walker, M. R., Freeman, S., Sloan, L. R. 1976, "Basking in Reflected Glory", Journal of Personality and Social Psychology, 34: 366-375.

Cohen, B., 1987, The Snow White Syndrome: All About Envy, London: Macmillan Publishers. D'Arms, Justin, “Envy”, The Stanford Encyclopedia of Philosophy (Spring 2017 Edition), Edward N. Zalta (ed.), URL = 
<https://plato.stanford.edu/archives/spr2017/entries/envy/>.

Descartes, R. 1985, The Passions of the Soul (1649), tr. by R. Stoothoof, Cambridge: Cambridge University Press.

Dryer, D. C. and Horowitz, L. M. 1997, “When Do Opposites Attract? Interpersonal Complementarity Versus Similarity," Journal of Personality and Social Psychology, 72(3): 592-603.

Dunn, J. and Kendrick, C. 1982, Siblings: Love, Envy, and Understanding, Cambridge (MA): Harvard University Press.

Ellman, C. S. 2000, “The empty mother: women's fear of their destructive envy,” Psychoanalytic Quarterly, 69: 633-657.

Exline, J. E. and Zell, A. L. 2008, Antidotes to Envy: A Conceptual Framework. In R. H. Smith (Ed.), Envy: Theory and Research (pp. 315-331). New York: OUP.

Fiske, S. 2011, Envy Up, Scorn Down: How Status Divides Us, Russell Sage Foundation.

Foster, G. M. 1972, “The anatomy of envy: A study in symbolic behavior,” Current Anthropology, 13: 165-202.

Gerhardt, J. 2009, “The Roots of Envy: The Unaesthetic Experience of the Tantalized/Dispossessed Self,” Psychoanalytic Dialogues, 19: 267-293.

Harcourt E. 2013, “The Place of Psychoanalysis in the History of Ethics,” Journal of Moral Philosophy, DOI 10.1163/17455243-4681030.

Harris, A. 2002, “Mothers, Monsters, Mentors," Studies in Gender and Sexuality, 3(3): 281-295.

Helm, Bennett, "Love", The Stanford Encyclopedia of Philosophy (Fall 2013 Edition), Edward N. Zalta (ed.), URL $=<$ https://plato.stanford.edu/archives $/$ fall2013/entries $/$ love $/>$.

Hume, D. 1978, A Treatise of Human Nature (1739), Oxford: Oxford University Press.

Kant, I. 1996, The Metaphysics of Morals (1797), tr. and ed. by M. J. Gregor, Cambridge: 
Cambridge University Press.

Kierkegaard, S. (1941). The Sickness Unto Death: A Christian Psychological Exposition For Upbuilding And Awakening (1849). New York: OUP.

Kolodny, N. 2003, “Love as Valuing a Relationship,” The Philosophical Review, 112: 135-89.

Konyndyk DeYoung, R. (2009). Glittering Vices: A new look at the seven deadly sins and their remedies. Grand Rapids: Brazos Press.

La Caze, M. (2001), "Envy and resentment”, Philosophical Explorations: An International Journal for the Philosophy of Mind and Action, 4(1):31-45

Lacewing, M. 2013, “Could Psychoanalysis Be a Science?” in Fulford, W. et al (eds.) The Oxford Handbook of Philosophy and Psychiatry.

LaVerde-Rubio, E. 2004, "Envy: one or many?” The International Journal of Psychoanalysis, 85: 401-418.

Lindholm, C. 2008, “Culture and Envy,” in Smith, R. H. (ed.), 227-244.

Miceli, M., and Castelfranchi, C. 2007, “The envious mind”, Cognition and Emotion, 21 (3): 449-479.

Nussbaum, M. 1990, Love's Knoweldge: Essays on Philosophy and Literature, OUP.

Parrott, W. G. 1991, “The emotional experiences of envy and jealousy,” in Salovey, P. (ed.), $3-30$.

Parrott, W. G., and Smith, R. H. 1993, "Distinguishing the experiences of envy and jealousy," Journal of Personality and Social Psychology, 64: 906-920.

Polledri, P. 2003, “Envy Revisited,” British Journal of Psychotherapy, 20(2): 195-218.

Protasi, S. 2016a, "Varieties of Envy," Philosophical Psychology, 29(4): 535-549.

Protasi, S. 2016b, “Loving People For Who They Are (Even When They Don't Love You Back," 24(1): 214-234. 
Rawls, J. 1971, A Theory of Justice, Cambridge, MA: Harvard University Press.

Rousseau, J. 2005, On the Origin of Inequality (1752), tr. by Cole, G. D. H., New York: Cosimo.

Shapiro Barash, S., 2007, Tripping the Prom Queen: The Truth About Women and Rivalry, London: Macmillan Publishers.

Schindler, I., Paech, J., \& Löwenbrück, F., (2015), "Linking admiration and adoration to selfexpansion: Different ways to enhance one's potential," Cognition and Emotion, 29(2): 292-310. doi:10.1080/02699931.2014.903230

Smith, R. H. (ed.) 2008, Envy: Theory and Research, Oxford: Oxford University Press.

Smith, R. H., and Kim, S. H. 2007, “Comprehending envy”, Psychological Bulletin, 133: 46-64.

Smith, R. H., Kim, S. H., and Parrott, G. W. 1988, "Envy and Jealousy: Semantic Problems and Experiential Distinctions," Personality and Social Psychology Bulletin, 14: 401-409.

Spinoza, B. 1949, Ethics (1677), ed. and tr. by Gutmann, J., New York: Hafner Publishing Company.

Stein, M. 1990, "Sibling Rivalry and the Problem of Envy," Journal of Analytical Psychology, 35: $161-174$.

Taylor, G. 1988, "Envy and jealousy: Emotions and vices," Midwest Studies in Philosophy, 13: 233-249.

Taylor, G. 2006, Deadly Vices, Oxford: Oxford University Press.

Tesser, A. and Collins, J. E. 1988, "Emotion in social reflection and comparison situations: Intuitive, systematic, and exploratory approaches", Journal of Personality and Social Psychology, 55: 695-709.

Thomas Aquinas 1947-48, Summa Theologica: Complete English Edition in Five Volumes (12651274), Notre Dame: Ave Maria Press. 
Thomason, K.T. 2015, “The Moral Value of Envy”, The Southern Journal of Philosophy, 53(1): $36-53$.

Uchino, B. N., Holt-Lunstad, J., Uno, D., and Flinders, J. B. 2001, "Heterogeneity in the social networks of young and older adults: prediction of mental health and cardiovascular reactivity during acute stress," Journal of Behavioral Medicine, 24: 261382.

van de Ven N., Zeelenberg M., Pieters R. 2011, "Why Envy Outperforms Admiration," Personality and Social Psychology Bulletin, 37(6): 784-795.

van de Ven N., Hoogland C. E., Smith R. H., van Dijk V. V., Breugelmans S. M. \& Zeelenberg M. 2014, "When envy leads to schadenfreude," Cognition and Emotion, DOI: $10.1080 / 02699931.2014 .961903$

van de Ven, N. 2015, "Envy and admiration: emotion and motivation following upward social comparison," Cognition and Emotion, DOI: 10.1080/02699931.2015.1087972

van de Ven, N. 2016, "Envy and Its Consequences: Why It Is Useful to Distinguish between Benign and Malicious Envy," Social and Personality Psychology Compass 10(6): 337-349, DOI: $10.1111 /$ spc3.12253

Zeavin, L. 2012, “The Analyst's Unconscious Reactions to the Baby in the Consulting Room," Journal of the American Psychoanalytic Association, 60: 517-525. 